\title{
MLL/AFF1 Fusion Gene
}

National Cancer Institute

\section{Source}

National Cancer Institute. MLL/AFF1 Fusion Gene. NCI Thesaurus. Code C99319.

A fusion gene $(\sim 12 \mathrm{~kb})$ that results from a chromosomal translocation $\mathrm{t}(4 ; 11)(\mathrm{q} 21 ; \mathrm{q} 23)$

which fuses the 5 ' half of the MLL gene to the 3 ' half of the AFF1 gene. This

rearrangement is associated with acute lymphocytic leukemia and other leukemia types. 